\title{
Vincetoxicum cardiostephanum A Threatened Sub-Endemic Species in Koh-e-Safaid Range, Pakistan
}

\author{
Wahid HUSSAIN ${ }^{1}$, Lal BADSHAH ${ }^{1}$, Asghar ALI $^{2}$, Farrukh HUSSAIN *3 \\ ORCID: 0000-0002-5730-4123; 0000-0002-88983608; 0000-0003-4074-1324; 0000-0001-6896-0911 \\ ${ }^{11}$ Department of Botany, University of Peshawar, 25000, Pakistan \\ ${ }^{2}$ Govt. Post Graduate College Matta, Swat, 19040, Pakistan \\ ${ }^{3}$ Department Of Biotechnology, Sarhad University of Science And Technology Peshawar, 25000, Pakistan
}

\begin{abstract}
Vincetoxicum cardiostephanum (Rech. F.) Rech. f. is a sub-endemic narrow species to Pakistan. The conservation status has been assessed according to International Union for Conservation of Nature Red List Categories and Criteria 2001. The genus Vincetoxicum is comprised of 20 species. Pakistan hosting 6 species including Vincetoxicum which is uniregional endemic to Upper Kurram, Pakistan. Earlier it was reported from Khaiwas by Aitchison (1881), Upper Kurram. This investigation was based on field trips conducted all over the Koh-e-Safaid ranges of Kurram valley, during April, 2015 to 2017. Based on the data collection, population size of the species was 43 individuals, Extent of occurrence $\left(3.1 \mathrm{~km}^{2}\right)$, Area of occupancy $\left(0.9 \mathrm{~km}^{2}\right)$. The taxon is under severe biotic stress due to uprooting \& overgrazing. Vincetoxicum cardiostephanum has been classified as Critical Endangered following IUCN Criteria 2001.
\end{abstract}

Key words: Vincetoxicum cardiostephanum, Sub-Endemic, Critical Endangered, Koh-e-Safaid, Pakistan

\section{Vincetoxicum cardiostephanum Pakistan, Koh-e-Safaid Range'de Dar Endemik Bir Tür Tehdit Ediyor}

\section{Özet}

Vincetoxicum cardiostephanum (Rech. F.) Rech. f. Pakistan'a göre dar bir endemik türdür. Koruma durumu Uluslararası Doğayı Koruma Birliği Kırmızı Liste Kategorileri ve Kriterler 2001'e göre değerlendirilmiştir. Vincetoxicum cinsi 20 türden oluşmaktadır. Pakistan, Yukarı Kurram, Pakistan için endemik olmayan Vincetoxicum da dahil olmak üzere 6 türe ev sahipliği yapıyor. Daha önce Aitchison (1881), Yukarı Kurram tarafından Khaiwas'dan bildirilmiştir. Bu araştırma, Nisan 2015 ile 2017 yılları arasında Kurram vadisinin Koh-e-Safaid aralıklarının tamamında gerçekleştirilen saha gezilerine dayanıyordu. , Doluluk alanı $(0.9 \mathrm{~km} 2)$. Takson kökünden sökülme ve otlatma nedeniyle ciddi biyotik stres altındadır. Vincetoxicum cardiostephanum, IUCN Criteria 2001'den sonra Kritik Tehlike Altında olarak sinıflandırılmıştır.

Anahtar kelimeler: Vincetoxicum cardiostephanum, Sub-Endemik, Kritik Tehlike Altında, Koh-e-Safaid, Pakistan

\section{Introduction}

Vincetoxicum cardiostephanum belongs to Family Asclepiadaceae, comprises 180 genera and 22,00 species distributed mainly in Tropical and Sub-tropical areas of the world; reported in Pakistan, 23 genera and 41 taxa (Figure 1). The genus Vincetoxicum has 10-20 species distributed in Asia, Europe, and Afghanistan. Pakistan represents 6 species i.e. Vincetoxicum arnottianum (wight)wight from Hazara, Vincetoxicum cardiostephanum from Kurram Agency, Vincetoxicum canesecens Wind Dene From Kashmir., Vincetoxicum hirundinaria Medik from Waziristan, Vincetoxicum sakesarense Ali \& S, Khatoon from Sargodha, and Vincetoxicum stocksiii Ali \& Khatoon from Baluchistan. Of these one taxon is Sub-endemic to Kurram and Afghanistan Pakistan [1].

\footnotetext{
* Corresponding author / Haberleşmeden sorumlu yazar: Tel.: +092926312103; Fax.: +092926310029; E-mail: wahidhussainwahid@ gmail.com (C) Copyright 2020 by Biological Diversity and Conservation $\quad$ Received: 23.06.2019 Published: 15.04.2020 BioDiCon. 838-0619
} 


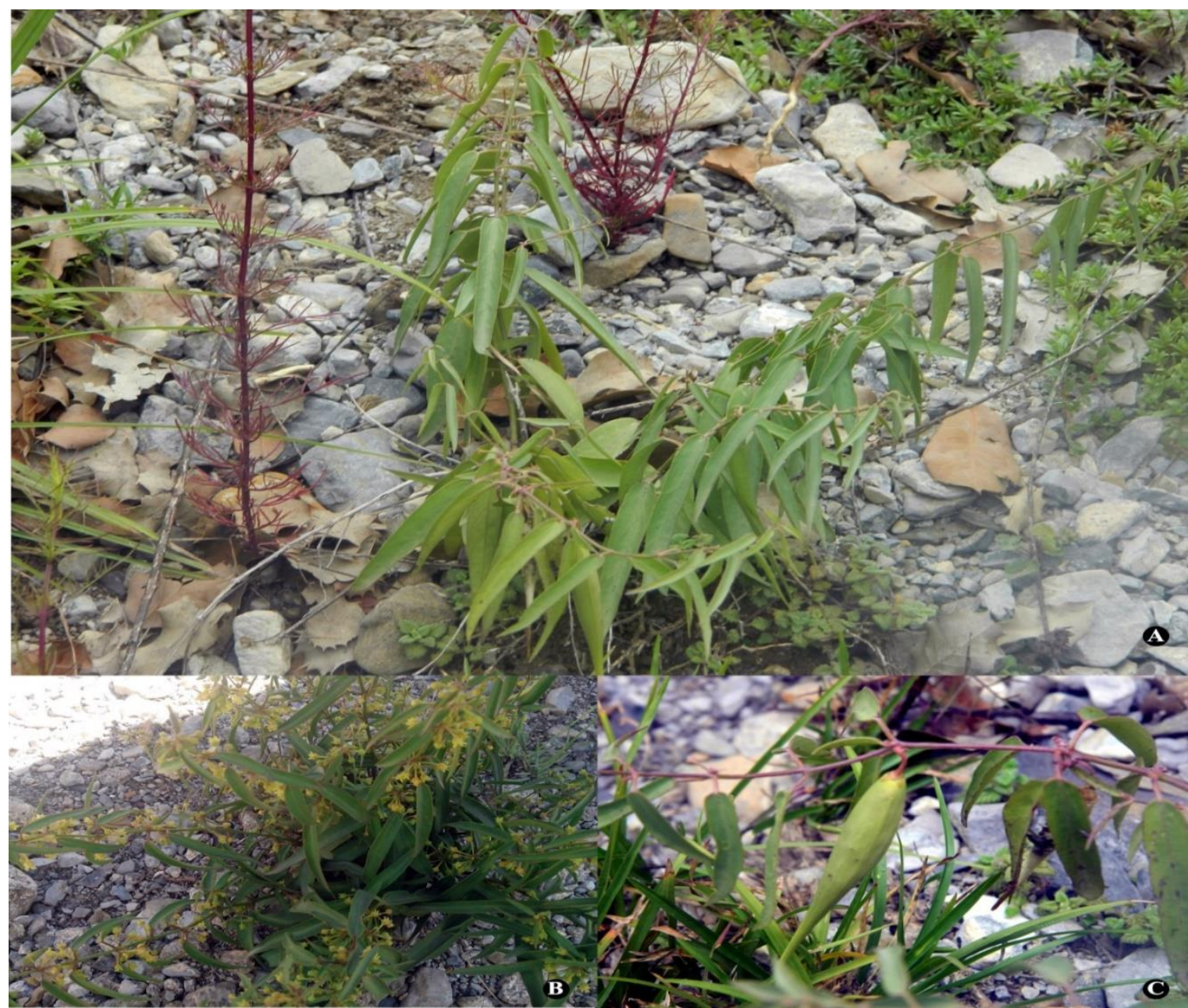

Figure1. Vincetoxicum cardiostephanum (Rech.f) Rech.f, A. Habit and Habitat; B. Plant in flowering; C. Mature plant

Nowadays extinction of plants has become headlines of the print and electronic media and they are taking interest of the future of these threatened species. International Union for Conservation of Nature is making incredible efforts to protect hundreds of species [2]. Different attributes effect the endemism includes uneven habitats and different climatic conditions and edaphic parameters within short space in highlands areas, and some of the anthropogenic activities such as unsustainable use of plants (uprooting), deforestation, grazing, and mining as results isolation of small species populations $[3,4,6,7,8]$. According to the recent studies about endemism have been emphasized, the role of pollination, life form and eco-physiological type effect the endemism at species and community level [9, 10, 11]. Pakistan has great diverse list of plants as a result of distinct geographical and topographic location. Above six thousand different vascular plants have been recorded, about 400 species are endemic [12]. As reported by IUCN Red List Criteria 2001, conservation of fifty-two species have been assessed, of these twenty-one species are Critically Endangered, ten species Endangered, two Vulnerable, eight possibly extinct [13-18]. This number rarely corresponds to around $0.8 \%$ of Pakistan's Flora. Therefore, the assessments of the status of conservation of the flora of Pakistan should focus in particular on endemic species of Pakistan. [12]. The objective of the present study was to assess the conservation status of Vincetoxicum cardiostephanum through to IUCN Red List Criteria [19].

\section{Materials and methods}

\subsection{Location}

Kurram is a newly-formed Tribal District of Khyber Pakhtunkhwa, Pakistan [20]. The global geographic position of Kurram is between $33^{\circ} 20^{\prime}$ to $34^{\circ} 10^{\prime}$ North latitudes and $69^{\circ} 50^{\prime}$ to $70^{\circ} 50^{\prime}$ East longitudes (Figure 4). It has total area of 3380 (square kilometer) and highest peak is Sikaram with 4,728 meters. It makes a natural boundary with Tora Bora Mountains of Afghanistan, and is snowcapped round the year [21, 22]. 


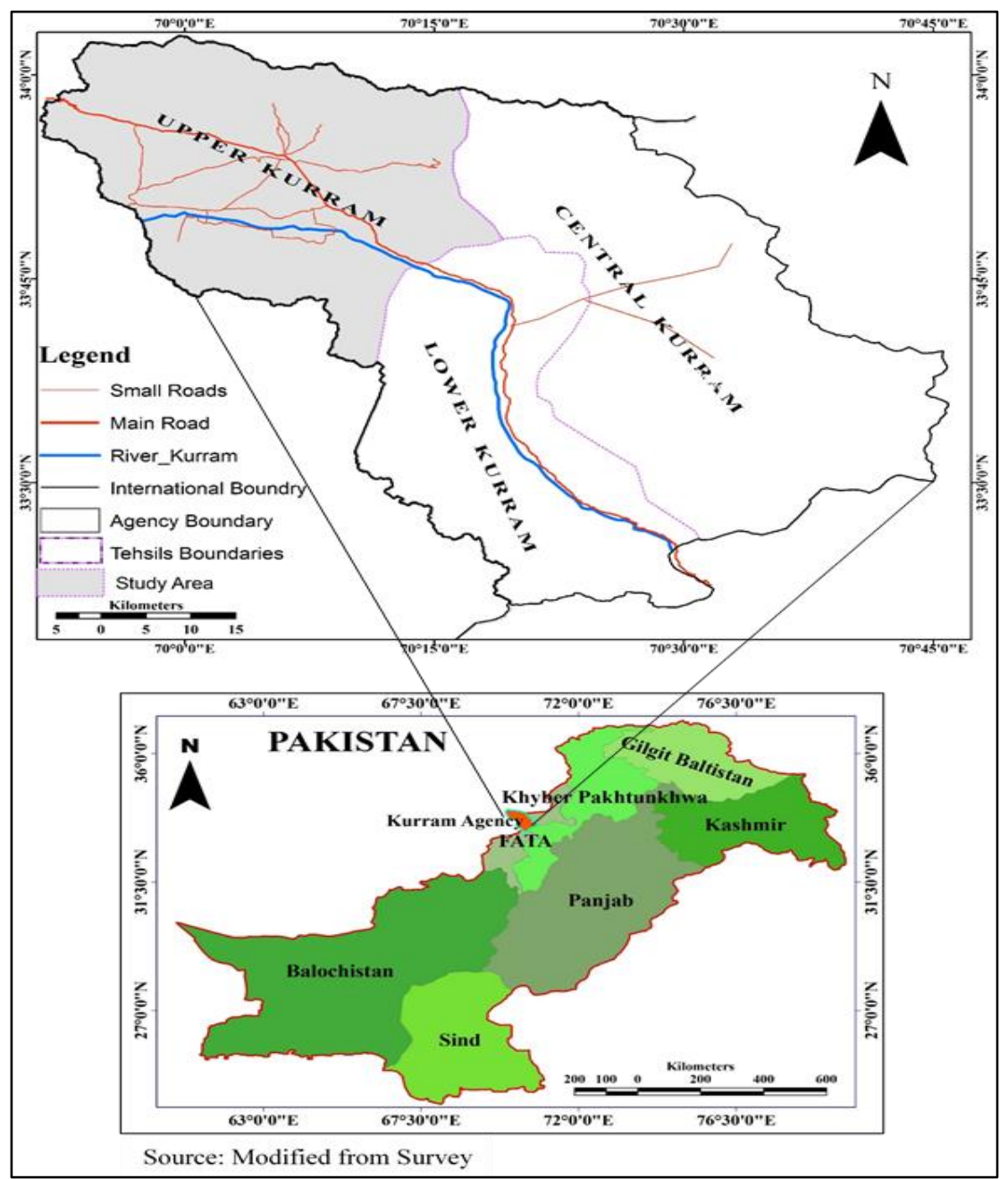

Figure 4. Location Map of Studay area: 1. Khaiwas 2. Gandaw

\subsection{Experimental design}

The objective of the current study was to assess the conservation status of Vincetoxicum cardiostephanum through to International Union for Conservation of Nature Red List Criteria [19]. For the data collection field trips were made through the whole Koh-e-Sufaid ranges of district Kurram, during March 2015 to August 2017.The geographic distribution, Size of population, Habit, Phenology, habitat features, types of propagation, life form, leaf size \& folk knowledge uses were recorded in the study area of the concerned taxa. Plants samples were collected preserved and voucher specimens were allotted. During the survey notebook, pencil, tags, polythene bags, newspaper and camera were used. In each trip specimens of complete plants were collected from two different localities. Plants specimen were tagged on the spot and identified with help of standard literature method [23, 24, 25]. The voucher specimen (W. Hussain,Voucher No. Bot. Huss. 055 (PUP) was placed in Herbarium; University of Peshawar for the further investigation. For the size of population, matured number of plants was calculated by totaling number of plants per unit area. Nature of habitation was calculated by observing grazing effect, anthropogenic impacts and approachability to an area, soil erosion, and ecological attributes. Ethnobotanical data was collected through; trips of the study area by interviewing 30 inhabitants. Conservation assessment of the species was done through International Union for Conservation of Nature Red List Criteria [19].

\section{Results}

\subsection{Habit and Taxonomy}

Vincetoxicum cardiostephanum is 350-400 millimeter tall glabrous perennial herb with many branches. Leaves c. 20-50 millimeter x 7-10 millimeter, ovate lanceolate, Flowers clustered in axillary cymes. Pedicels 1-6 millimeter long, Calyx 2.6 millimeter long, Corolla c. 4.5 millimeter long, pale-green, lobes glabrous, and Corona lobes cordate-truncate. Fruit 53-67 millimeter in length follicle (Fig.1) 


\subsection{Habitat and Community Structure}

This species grows between the transition zone of subtropical and temperate zone (2000-2250 meter). Most individuals of the species were growing on the moist gentle North and South facing slopes in sparsely dense forest of Quercus baloot Griffith. About 31 taxon were present as linked with this species. The leading taxon viz., Quercus baloot Griffith, Leptorhabdos parviflora (Benth.) Benth, Thymus linearis Benth., Sophora mollis (Royle) Baker., Rabdosia rugosa (Wall ex.Benth.), Scutellaria orientalis L. and Themeda anathera (Nees ex Steud) Hack in DC were observed. These 31 species were from 16 families and 30 genera as shown in Table 1.

Table 1. Recorded associates of Vincetoxicum cardiostephanum with their ecological characteristics

\begin{tabular}{|c|c|c|c|c|}
\hline S.No & Family & Name & Habit & Life form \\
\hline 1 & Asclepiadaceae & Vincetoxicum cardiostephanum(Rech.f) Rech.f & Herb & Geophyte \\
\hline 2 & Anacardiaceae & Cotinus coggyria Scop. & Shrub & Nanophanerophytes \\
\hline 3 & Asteraceae & Artemisia biennis Willd. & Herb & Chamaephyte \\
\hline 4 & Asteraceae & Circium falconeri (Hook. F) Petrak & Herb & Therophyte \\
\hline 5 & Asteraceae & Heteropappus altaicus Willd & Herb & Therophyte \\
\hline 6 & Asteraceae & Hertia intermedia (Boiss) O. Ktze & Shrub & Nanophanerophytes \\
\hline 7 & Asteraceae & Launea sps & Herb & Geophyte \\
\hline 8 & Asteraceae & Tagates minuta $\mathrm{L}$. & Herb & Therophyte \\
\hline 9 & Berberidaceae & Berberis lycium Royle & Shrub & Nanophanerophytes \\
\hline 10 & Boraginaceae & Cynoglossum glochiadum Wall.ex Benth. & Herb & Hemicryptophyte \\
\hline 11 & Dipsacaceae & Scabiosa columbavia $\mathrm{L}$. & Herb & Hemicryptophyte \\
\hline 12 & Fagaceae & Quercus baloot Griff. & Tree & Phnerophyte \\
\hline 13 & Lamiaceae & Thymus linearis Benth. & Herb & Hemicryptophyte \\
\hline 14 & Lamiaceae & Perovskia atriplicifolia Benth & herb & Nanophanerophytes \\
\hline 15 & Lamiaceae & Rabdosia rugosa (Wall ex. Benth) & Shrub & Nanophanerophytes \\
\hline 16 & Lamiaceae & Salvia reflexa Hormn & Herb & Therophyte \\
\hline 17 & Lamiaceae & Scutellaria orientalis & Herb & Hemicryptophyte \\
\hline 18 & Scrophulariaceae & Leptorhabdos parviflora(Benth).Benth & Herb & Therophyte \\
\hline 19 & Solanaceae & Solanum villosum $\mathrm{L}$. & Herb & Therophyte \\
\hline 20 & Papilionaceae & Indigofera heterantha Well.ex Brandis & Shrub & Phanerophyte \\
\hline 21 & Papilionaceae & Sophora mollis (Royle) Baker & Shrub & Chamaephyte \\
\hline 22 & Papilionaceae & $\begin{array}{l}\text { Caragana brevispina var. brevispina Royle ex. } \\
\text { Benth }\end{array}$ & Shrub & Chamaephyte \\
\hline 23 & Poaceae & Aristida cyanantha Nees ex Steud & Herb & Hemicryptophytes \\
\hline 24 & Poaceae & $\begin{array}{l}\text { Themeda anathera (Nees ex Steud.) } \\
\text { Hack }\end{array}$ & Herb & Hemicryptophytes \\
\hline 25 & Polygalaceae & Polygala abysinica R.Br.Ex.fresen & Herb & Therophyte \\
\hline 26 & Primulaceae & Androsace rotundifolia & Herb & Geophyte \\
\hline 27 & Rosaceae & Cotoneaster microphyllus var. thymifolius. & Shrub & Phanerophyte \\
\hline 28 & Rosaceae & $\begin{array}{l}\text { Cotoneaster macrocrophyllus (Lindl.) } \\
\text { Schneider. }\end{array}$ & Shrub & Phanerophyte \\
\hline 29 & Rosaceae & Spiraea corymbosa Raf. & Shrub & Phanerophyte \\
\hline 30 & Rosaceae & Rosa Webbenia Wall ex. Royle & Shrub & Nanophanerophytes \\
\hline 31 & Thymelaeaceae & Daphne oleoides Schreb. & Shrub & Nanophanerophytes \\
\hline
\end{tabular}

\subsection{Distribution}

Generally, this species is restricted to Village Shalozan Wazir Takhat Kaiwas and Nawoo Ghar Gandaw of Kohe-Safaid mountain range. During the survey it has been observed that some fragmented areas in the study area (Table 3 ). Presence of taxon was frequently restricted to north \& south facing slopes in rocky area but mean while some plants of the specie were also present in sparsely dense forest of Quercus baloot, Leptorhabdos parviflora, Thymus linearis, Sophora mollis, Rabdosia rugosa, Scutellaria orientalis and Themeda anathera. This species is severely endemic to the study area. All the total locations collectively cover an area of approximately $3.1 \mathrm{Km}^{2}$ as the extent of occurrence. The estimated collective occupation area was $0.9 \mathrm{~km}^{2}$ (Table 2). 
Table 2. Vincetoxicum cardiostephanum (Rech.f) Rech. f .: Summary of geographic range

viz. Extent of occurrence \& area of occupancy in in $\mathrm{Km}^{\mathbf{2}}$

Extent of occurrence in $\mathrm{Km}^{2}$

3.1
Area of occupancy Area in $\mathrm{Km}^{2}$

0.9

\subsection{Population Size}

Population size of Vincetoxicum cardiostephanum was recorded from village Khaiwas from two different areas (Table 3). Maximum number of individuals (population size) was reported from Wazir Takhat Khaiwas (24) individual plants and less number of individual plants (19) from Nawoo Ghar Gandaw (Figure 4).

Table 3. Population size detail of Vincetoxicum cardiostephanum from two reported spots

\begin{tabular}{|c|c|c|c|c|c|}
\hline S.No & Locality & Altitude (m) & Coordinates & $\begin{array}{l}\text { Population } \\
\text { Size }\end{array}$ & Percentage \\
\hline 1 & Wazir Takhat Khaiwas & $2198 \mathrm{~m}$ & $\begin{array}{l}33^{\circ} 57.73 .1 \mathrm{~N} \\
069^{\circ} 59831 \mathrm{E}\end{array}$ & 24 & 55.81 \\
\hline 2 & Nawoo Ghar Gandaw & $2231 \mathrm{~m}$ & $\begin{array}{l}33^{\circ} 57.62 .6 \mathrm{~N} \\
069^{\circ} 59604 \mathrm{E}\end{array}$ & 19 & 44.18 \\
\hline
\end{tabular}

\subsection{Mode of reproduction}

During the study period two kind of reproduction were reported vs. Sexual \& Asexual.

3.6 Sexual Reproduction

It is the most common method of reproduction. Vincetoxicum cardiostephanum starts flowers from the mid of April to the end of July. The population peak flowering period was recorded after 25 th May to $5^{\text {th }}$ July. The average number of fruits per individual was recorded 2-3 (Table 4; Figure 3).

Table 4. Vincetoxicum cardiostephanum numerical analysis of the habits of the plants in relation to the habitat.

\begin{tabular}{llll}
\hline S. No & Habit & Observed species & Percentage in the Total \\
\hline 1 & Herb & 18 & 58 \\
\hline 2 & Shrub & 12 & 38.70 \\
\hline 3 & Tree & 01 & 3.2 \\
\hline
\end{tabular}

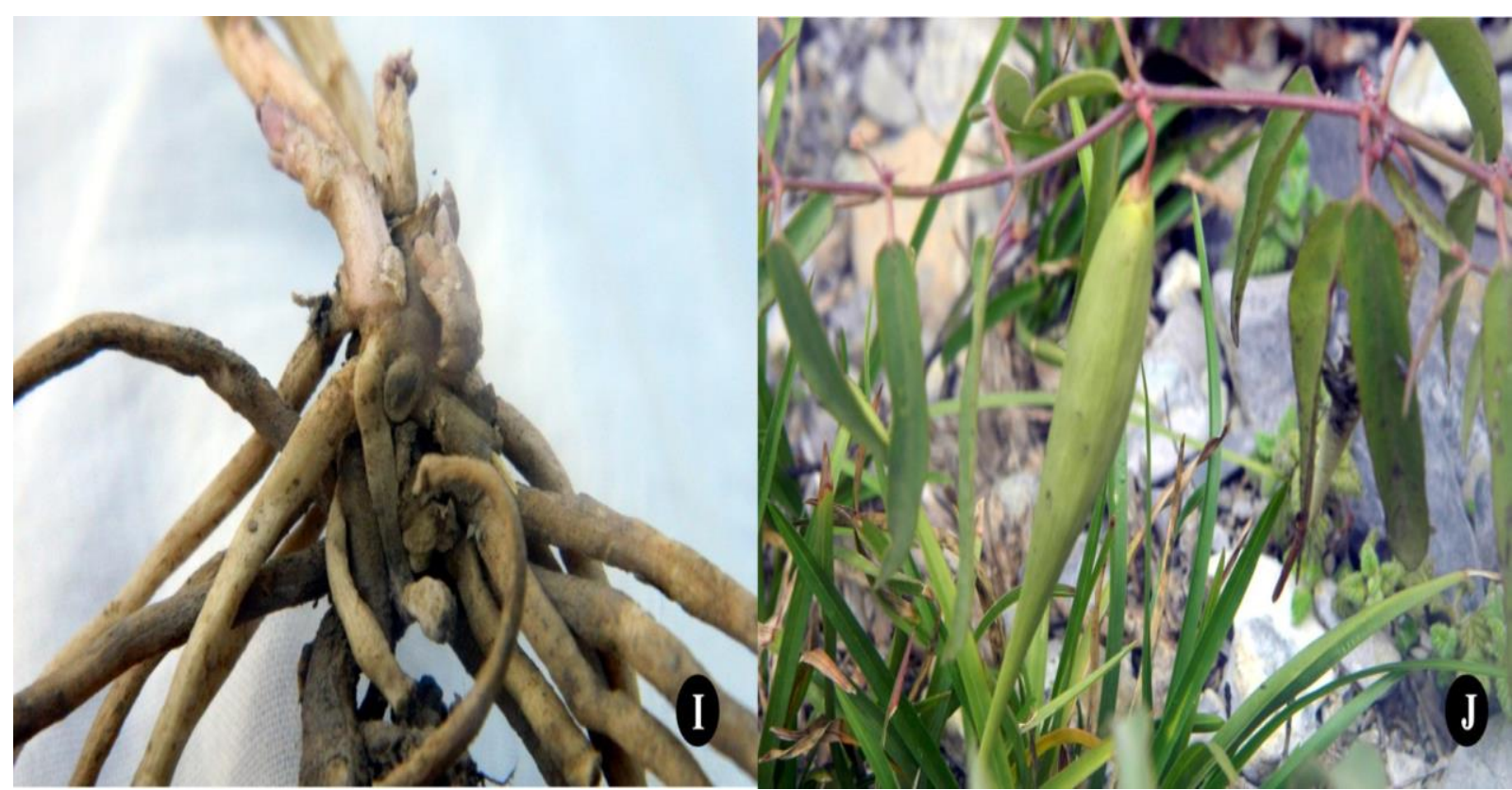

Figure 3. Reproduction of Vincetoxicum cardiostephanum I, Asexual (buds); J, Sexual (Seeds) 


\subsection{Asexual reproduction}

Asexually Vincetoxicum cardiostephanum is reproduce through vegetative method. The reproductive tissues like rhizome are sprout during favorable conditions and giving rise to new individual (Figure2)

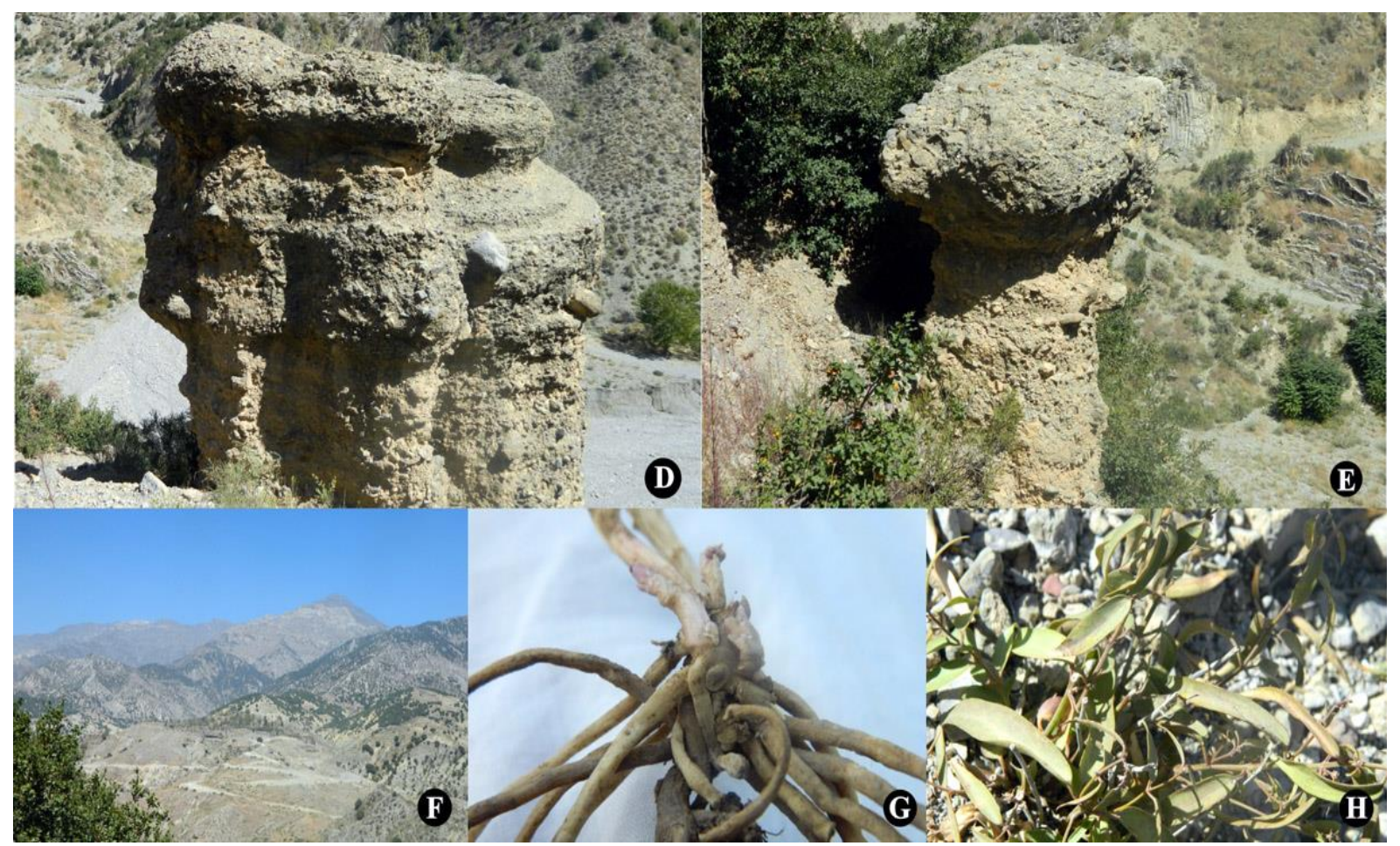

Figure2. Anthropogenic \& natural threats to Vincetoxicum cardiostephanum: D \& E, Erosion, F, Roads construction, G, Uprooting, H, Grazing

\section{Conclusions and discussion}

This specie was reported previously from Khaiwas Koh-e-Safaid range Upper Kuram by Aitchison. During the current survey, this taxon was recorded from the two areas of the village Khaiwas. In these two areas, the occurrence of the species is limited to mountains slopes of Sub-Tropical Zone. During the field observation this taxon was found to be in isolated micro habitats. Current results showed that the nature of taxon is limited and isolated.

According to Rabinowitz [27], rarity of a taxon is due to small size population, pint distribution area, specific habitation or a grouping of all these units. In the case of Vincetoxicum cardiostephanum, an average presence of 24 individuals plants in locality 01 and 19 individuals in locality 02 and their restriction in particular habitat from 2165-2250 meters and presence c 0.9 Kilometer squares the area of occupancy show that this is an actual rare species (Table. 3). According to International Union for Conservation of Nature Red List Criteria 2001 [20] when a matured plants $>250$ (i.e. 43) and habitation is constantly degraded as result of sever grazing and facing many anthropogenic threats, Vincetoxicum cardiostephanum belongs to criterion "C" of critically endangered group. Moreover, 90\% population of the concerned species is limited in Wazir Takhat Khaiwas, this numeral falls under sub-criterion 2 (ii) of " C" of Critically Endangered Category. The extent of occurrence is nearly 3.1 Kilometer square that is below 100 Kilometer square and area of occupancy is 0.9 Kilometer square that is below 10 Kilometer square. Moreover, this taxon is greatly fragmented into 2 areas and habitation is also degraded. On the bases of current findings this taxa is placed under $\mathrm{B}_{1} \& \mathrm{~B}_{2}$ of critically endangered group. For example, if the matured plants are recorded below fifty plants and taxon is classified under the criterion "D". Short geographical zones, very small population size, overgrazing and fragmented habitation strongly suggest that Vincetoxicum cardiostephanum should be consider as critically endangered. By following the hierarchical alphanumeric numbering system of the criteria [20], assessment of the conservation status of Vincetoxicum cardiostephanum summarized in this way:

\section{CRB1ab (iii) +2ab (iii); C2 (ii)}

Where CR, Critically Endangered species; B, Geographic ranges; 1, a Extent of occurrence; 2 (B), Area of occupancy; a, Severely disjointed; b, continuing decline, observed, predicted; iii, Quality of habitat; C, Estimated populace size; 2 (C), A continuously decreasing no. of matured plants; ii, As a minimum 88\% matured plants are in one sub-population (Table. 5). 
Table 5. Summary of known Localities, Population Size, Geographical Range and Various Anthropogenic and Natural Threats Observed in the Study Area

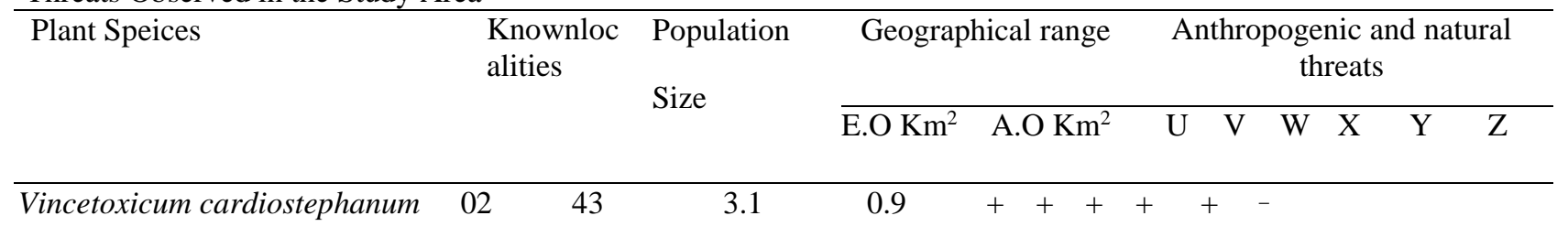

Key: E.O; Extent of occurrence, A.O; Area of occupancy, U, Medicinal uses, V, uprooting, W, Grazing X, Road Construction, Y, Soil Erosion, Z, Deforestation ( ${ }^{+}$Present, - Absent $)$

4.1 Anthropogenic impacts

Over grazing and unwise medicinal uses were recorded as the main threats to concern species.

\subsection{Grazing}

Vincetoxicum cardiostephanum is palatable plant during pre-reproductive stage. The local population grazed their livestock in the study areas, which seriously affected the habitats of concern specie. In each season, these individual plants were grazed during pre-reproductive stage before the formation of fruits as result the concern specie is in threaten position (Tab. Figure 2).

\subsection{Unsustainable Medicinal uses}

Vincetoxicum cardiostephanum is highly medicinal plant and local people, who are living in the foothill of kohe-Safaid range, uproots the whole plants. The fresh leaves were shade dried crushed fine powder were used for the treatment of chest problems, hepatitis $\mathrm{C}$ and rhizome are used for the blood purification and urinary infections as reported by the local inhabitants. Due to uprooting the concern specie become threatens (Figure 2)

\subsection{Road construction}

Due to road construction to locality Khaiwas, the road passes through the habitat rich area of the specie which added a serious threat (Figure 2).

\subsection{Recommendations}

i) Vincetoxicum cardiostephanum had better to include in the Red list category of taxa of Pakistan.

ii) The cultivation of Vincetoxicum cardiostephanum in botanical gardens should be encouraged to protect them from extinction.

iii) Grazing in research area is should be banned through local Bandar system to protect the concern specie.

iv) To educate the local inhabitants through awareness program to avoid the unsustainable use.

\section{Acknowledgement}

This study is part of the Doctorial research work of the corresponding author. Authors thank the locals of the area for providing some valuable information during the field visits.

\section{References}

[1] Ali, S. I., Khatoon, A. (1972). Family Asclepiadaceae, Flora of Pakistan. Pakistan Journal of Botany, 14(1), 3139.

[2] Masseti, M. (2009). Protected areas and endemic species. Biodiversity Conservation and Habitat Management, $1(2), 1,118$.

[3] Shaheen, H., Aziz, S., Dar, M. E. U. I. (2017). Ecosystem services and structure of western Himalayan temperate forests stands in Neelum valley, Pakistan. Pakistan Journal of Botany, 49(2), 707-714.

[4] Alam, J., Ali, S. I. (2015). Astragalus Clarkeanus Ali: A Threatened and Narrow Endemic Species In GilgitBaltistan, Pakistan. Pakistan Journal of Botany, 47, 43-49. 
[5] Hussain, W., Badshah, L., Ullah, M., Ali, M., Ali, A., \& Hussain, F. (2018). Quantitativestudy of medicinal plants used by the communities residing in Koh-e- Safaid Range, northern akistani-Afghan borders. Journal of ethnobiology and ethnomedicine, 14(1), 30.

[6] Van d, H., T, Consiglio, J. (2004). Distribution and conservation significance of endemic species of flowering plants in Peru. Biodiversity and conservation, 13(9): 1699-1713.

[7] Kruckeberg, A. R., Rabinowitz, D. (1985). Biological aspects of endemism in higher plants. Annual Review of Ecology Systematics, 16, 447-479.

[8] Major, J. (1988). Endemism: a botanical perspective. In: Myers A.A. and Giller P.S. (eds) Analytical Biogeography, An Integrated Approach to the Study of Animal and Plant Distributions. Chapman \& Hall, London.

[9] Mir, A. H., Upadhaya, K., \& Choudhury, H. (2014). Diversity of endemic and threatened ethnomedicinal plant species in Meghalaya, North-East India. Int Res J Environ Sci, 3(12), 64-78.

[10] Knapp, S. (2002). Assessing patterns of plant endemism in Neotropical Uplands. The Botanical Review, 68, 2237.

[11] Luteyn, J. L. (2002). Diversity, adaptation \& endemism in Neotropical Ericaceae biogeographical patterns in the Vaccinieae. The Botanical Review, 68, 55-87.

[12] Muhammad, S., J, Alam., Ijaz, F., Z, Iqbal. (2017). Evaluation of the Conservation Status of Rhododendron Afghanicum Aitch. \& Hemsl.: A Narrow Endemic Species for Pakistan. Pakistan Journal of Botany, 49(4), $1387-$ 1394.

[13] Abbas, H., Qaiser, M., Alam, J. (2010). Conservation status of Cada heterotricha Stocks (Capparidaceae): an endangered species in Pakistan. Pakistan Journal of Botany, 42(1), 35-46.

[14] Alam, J., Ali, S. I. (2009). Conservation status of Astragalus gilgitensis Ali (Fabaceae): A critically endangered species in Gilgit District, Pakistan. Phyton (Horn, Austria), 48: 211-223.

[15] Alam, J., Ali, S. I. (2010). Contribution to the Red List of the Plants of Pakistan. Pakistan Journal of Botany, 42(5): 2967-2971.

[16] Ali, H., Qaiser, M. (2010). Contribution to the Red List of Pakistan: A case study of Astragalus gahiratensis. (Fabaceae-Papilionoideae). Pakistan Journal of Botany, 4(2), 1523-1528.

[17] Sezer, O., Özgisi, K., Yaylaci, Ö. K., \& Koyuncu, O. (2013). Some morpho-anatomical studies on rare endemic Muscari sivrihisardaghlarensis. Biological Diversity and Journal onservation, 6(2), 26-33.

[18] Mukassabi, T. A., Thomas, P. A., \& Elmogasapi, A. (2017). Medicinal plants in Cyrenaica, Libya: existence and extinction. Biological Diversity and Conservation,10 (2), 183-193.

[19] Anonymous. (2001). IUCN Red List Categories and Criteria: Version 3.1. IUCN Species Survival Commission IUCN, Gland, Switzerland and Cambridge, U.K.

[20] Stewart, R. R. (1982). History and Exploration of Plants in Pakistan and Adjoining Areas (Flora of Pakistan) Pan Graphics Ltd., Islamabad.

[21] Hussain, W., Hussain, J., Roshan A., Ikhtir K., Shinwari, Z. K. (2012). Tradable and Conservation status of medicinal plants Kurram Valley,Parachinar, Pakistan. Journal of Applied Pharmaceutical Science, 2(10), 066070 .

[22] Badshah, L., Hussain, F., Sher, Z. (2016). Floristic Inventory, Ecological Characteristics \& Biological Spectrum of Plants of Parachinar, Kurram Agency, Pakistan. Pak. J. Bot, 48, 1547-1558.

[23] Ali, S. I., Qaiser, M. (1995-2016). Flora of Pakistan. Department of Botany, University of Karachi.

[24] Ali, S. I., Nasir, Y, J. (1989-1992). Flora of Pakistan, Islamabad, Karachi.

[25] Nasir, E., Ali, S. I. (1970-1989). Flora of Pakistan, Islamabad, Karachi.

[26] Aitchison, J.E.T. (1881-1882). On the Flora of the Kurram Valley \& Afghanistan. 30:1- 113,139-200.

[27] Rabinowitz, D. (1981). Seven forms of rarity. The Biological Aspects of Rare Plant Conservation. (Eds.): Synge. Wiley \& Sons Ltd. 205-217. 